\title{
Greetings and Salutations in Erasmus
}

\author{
ALEXANDER DALZELL
}

RÉSUMÉ: Les formules de salutations dans l'œuvre d'Érasme

Les formules de salutations qui se trouvent en tête des lettres d'Érasme posent des problèmes difficiles au traducteur. Il n'y a pas d'équivalents évidents en anglais moderne et i! est donc tentant de les omettre ou de se réfugier dans des formules de politesse d'une équivalence douteuse. Cependant, le traducteur devrait les prendre au sérieux puisqu'elles donnent souvent une indication sur le ton de la lettre ou les relations entre les correspondants. Les écrivains humanistes développèrent un protocole élaboré pour les salutations épistolaires et Érasme lui-même écrivit longuement sur le sujet dans son De conscribendis epistolis. Les formules ont une longue histoire, remontant jusqu'à l'antiquité classique. Les salutations de Cicéron sont en général courtes et simples, mais les formules traditionnelles furent abandonnées peu à peu en faveur de formules de politesse plus élaborées et plus flatteuses. En théorie, Érasme était en faveur de la simplicité classique, mais dans la pratique il fit des concessions aux conventions contemporaines et à la vanité humaine. L'article se termine par une discussion de l'enseignement d'Érasme sur le sujet et sur quelques exemples des problèmes auxquels le traducteur doit faire face.

I

I wish to discuss a problem that confronts the translator of the letters of Erasmus. Translation is always a difficult art and it is not easy to catch the right tone to match the variety and subtlety of a consummate stylist like Erasmus. But the passages which have caused me the greatest difficulty are those for which there is no real equivalent in modern English because we no longer wish to say that sort of thing. The translator of the letters meets a problem at the very beginning. What is he to do with the elaborate courtesies with which sixteenth-century letter-writers greeted their friends and patrons? In the Translators' Note to the first volume of the correspondence in the Collected Works of Erasmus Sir Roger Mynors and Douglas Thompson wrote as follows: 
Nor are we satisfied with our treatment of the opening and closing formulae of the letters. Except where the original survives, we cannot always be sure how a letter began and ended, and the forms then in current use ('to the most ornate theologian greeting') cannot be Englished without some discomfort.

I have felt that discomfort constantly in my own translations. It is difficult, perhaps impossible, to find a modern equivalent for these courteous phrases that will not sound contrived and artificial to the modern reader. Does it matter what we do with these phrases? Well, Erasmus thought the matter sufficiently important to write about it at length in the De conscribendis epistolis. And behind the De conscribendis epistolis stood centuries of theorizing beginning in classical times and continuing through the writers of the Ars dictaminis to Erasmus' own day. So it may be worthwhile giving the matter some consideration. I propose to say something about the history of epistolary greetings, then to examine what Erasmus has to say on the subject, and finally to raise the question of translation.

But first, a word about text. The policy of the CWE edition of the correspondence is to translate Allen's text. But the salutation which appears at the head of a letter in Allen's edition is not always what was in the original letter. In a letter to Margaret of Angoulême, written in 1525, she is described in the heading as Queen of Navarre, although she did not marry Henri d'Albret until 1527. Clearly the letter was edited when it was prepared for publication in the Opus epistolarum of 1529. In Ep 348 Thomas Wolsey is addressed as 'cardinal,' though he had not yet been created cardinal when the letter was written. It is likely that other changes have been made which cannot be so easily detected. There are salutations in the Deventer book which have been corrected in Erasmus' own handwriting. There are cases where we have three copies of the same letter, all with different salutations. Of the large number of letters which exist in manuscript some have salutations and some do not. There is no suggestion in the De conscribendis epistolis that salutations are optional. Where the salutation is missing, we may guess that it was written on the back of the letter. Erasmus' contemporary, Francesco Negro, defines the salutation as that which is written on the front or the back of a letter. ${ }^{1}$ Many of our sources are copies and perhaps in some cases the copyist has saved himself some effort by omitting the purely formulaic opening. As a result of this confusion in our sources, it was necessary to develop an editorial policy. Hence the decision to translate whatever Allen printed. In a comparable situation, when dealing with the letters of Cicero to Atticus (where the 
salutations are spurious) the French editor, L-A Constans, decided to leave them out. But much would be lost if we were to follow a similar policy in dealing with the correspondence of Erasmus. It must always be remembered, however, that the salutations in our texts may have been edited or altered in transmission.

The problem of translating Erasmus' elaborate courtesies is not limited to the salutations. It was customary to reintroduce the recipient's name, with suitably flattering epithets, in the body of the letter itself. These unexpected vocatives may strike the modern reader as even more artificial than similar language in the heading. Both present problems to the translator, and although I shall deal mostly with the salutations, I have both types of address in mind.

The salutation has a long history. The grammatical structure which provides its basic shape is likely to have originated with the Greeks, but it is in its Latin form that it is known to us, that is to say, in the form which Cicero used: Cicero Trebatio salutem [dicit] / 'Cicero to Trebatius, greeting.' The theorists of the Middle Ages divided this simple phrase into three parts and attached names to each of them. Thus, in our example, Cicero's name is the intitulatio, Trebatio is the inscriptio, and salutem is the salutatio. Following normal practice, I shall use the word 'salutation' for the whole phrase. Each part of the phrase was liable to be expanded, but classical Latin was very reserved in this matter. Cicero sometimes adds the title of an office like 'proconsul' for example, and occasionally, when writing to members of his family, he uses a term of endearment, "to his darling daughter'; or he may add the word suus, 'to his own Terentia.' Erasmus thought that this was an innovation of Pliny's, but he was mistaken. I may say in passing that the addition of this humble adjective did not escape the relentless theorists of the Middle Ages, and they laid down rules for its use. The most common inscription in a papal letter is filio or filiis - the Pope sends greetings and apostolic blessing to his son or to his sons. The theorists said he must never use suus 'to his own son,' for that might imply, as they put it, a 'carnal relationship.' The prohibition was not observed in practice, though it is interesting that most of the papal letters in the Erasmian corpus do seem to conform to the rulc. Exceptions might be made for eminent persons. Thus Pope Leo addressed Henry VIII as carissimus in Christo noster filius (Ep 339). This, however, is not the usual form of papal greeting in the correspondence: presumably it was intended as a special mark of respect.

The word which is understood and which completes the sense of the salutation is dicit, so the whole phrase means 'Cicero expresses his good 


\section{4 / Renaissance and Reformation}

wishes to Trebatius' or 'Cicero says "greetings" to Trebatius.' But the verb was generally omitted or replaced by the single letter $d$, and eventually it was forgotten, making it possible to develop the phrase in ways which Cicero could not have foreseen. In the Middle Ages salutem is sometimes replaced by an infinitive. ${ }^{2}$ This somewhat ungrammatical construction is generally avoided by the Humanists, though there is an example in a letter of 1514 from Gregor Reisch (Ep 309): F. Gregorius, prior Carthusiae, domino Erasmo eternam in Domino consequi salutem / 'Gregor, prior of the Charterhouse, to Master Erasmus, [may he] obtain eternal salvation in the Lord.'

In the course of history the Latin for 'greeting' turned out to be a loaded word, for it was the Christian term for salvation. With the loss of the verb of 'saying,' it was possible to turn the whole phrase round and interpret it as 'X prays for eternal salvation for Y.' Hence in Christian writers the salutation often includes the phrase aeternam salutem or aeternam in Christo salutem. Sometimes the writer puns on the two senses of salutem, and this practice carries over into our period. What, for example, does Duke George of Saxony mean when he wishes Erasmus salutem, gratiam et favorem (Ep 1448)? The phrase or a variant of it occurs several times in the correspondence and it is usually translated literally as 'greeting, grace and favour.' But salutem may have more than one sense in this context. A similar problem arises in Letter 834 addressed to Henry VIII: Salutem et immortalitatem, serenissime Rex. Does this mean 'prosperity and undying fame,' as it is translated in our edition, or 'salvation and eternal life?' Or could it mean both? At all events the connection of salutem in these salutations with the Christian doctrine of salvation was so strong that some writers thought it inappropriate to use it in writing to a Jew or an infidel. Francesco Negro suggested that, in writing to unbelievers, one should avoid the word altogether and substitute something like 'saner thoughts and better counsel.' Similar advice is to be found, often expressed in more violent and racist terms, in the Medieval dictamen. ${ }^{3}$ In the De conscribendis epistolis Erasmus is very critical of any substitutions for salutem, describing such departures from the norm as the 'height of stupidity.' He argues on good theological grounds that, since nothing is more desirable than salvation, no better greeting can be devised.

As this citation may suggest, Erasmus' treatment of salutations in his De conscribendis epistolis is often highly polemical. He begins with an attack on the use of the complimentary plural. This was a matter of some contemporary interest because of the development in the Romance languages of the distinction between the second person singular as a familiar form and the second person plural as more formal and polite. Francis I 
is said to have forbidden writers and poets, on pain of being whipped, to address him as 'tu.' Erasmus refuses to acknowledge any such rule for the Latin language, and in his own letters to Francis, he always uses the singular $t u$ and tua. As far as Latin is concerned, Erasmus regarded the use of the plural of the pronoun vos and the plural possessive vester in reference to a single person as a solecism. I believe he is right about the pronoun, which is not used during the high Classical period as a singular; but the possessive adjective vester in reference to one person does occur, at least as early as Catullus. ${ }^{4}$ Erasmus cites an example from Pliny of vester used of one person, but this in fact is a genuine plural. ${ }^{5}$ Erasmus tried to avoid the embarrassment of catching one of his favourite authors in a solecism by supposing that the letter was spurious. But there is no need for such desperate measures. This whole discussion is of some interest to the philologist, as is his discussion of the commoner use of plural for singular in the first person (what we sometimes call the 'editorial we'). His approach is highly moralistic. He notes that good Latin writers often use this idiom, as he does himself, but suggests that it was modesty, not arrogance, that inspired the usage: Roman statesmen wished to share the credit for their actions with others and so referred to themselves as 'we'; in contrast, he complains, modern writers use it as a mark of pride. This may be good moralizing, but as philology it is nonsense.

What upset Erasmus even more was the use of the plural possessive with abstract nouns. This use of abstracts, which gave us such English phrases as 'your Reverence' and 'your Eminence,' seems to have originated with Greek. But Latin can spawn such phrases with equal facility and they are the despair of the translator. In addition to 'your reverence' we have 'your piety,' 'your paternity,' 'your amplitude,' and dozens of others including tua acrimonia. It is sometimes difficult to know when these locutions are to be treated as titles and when they should be integrated into the sentence. Phrases like 'I am pleased that your highness has taken notice of my humility' illustrate the point. According to the context, this might mean either 'I am delighted that your Highness, or your Excellency, has taken notice of a poor person like myself or 'I am pleased that someone as exalted as you should have time for a humble person like myself.' Such locutions are common in the correspondence of Erasmus, and he does not object to them except where the plural form is used, e.g. vestra celsitudo for tua celsitudo. Erasmus makes the wicked suggestion that the plural might be reserved for bishops with a plurality of benefices. 
With regard to the salutation itself, Erasmus makes it clear that he would prefer to return to the simplicity of Roman practice, but he recognizes that one must make some concessions to convention and to human pride. Generally, in writing to his humanist friends, he uses the simplest form of greeting without amplification or decoration. Thus 'Erasmus to his friend Budé, greeting' and Budé to Erasmus similarly. Only when there is special justification is the formula changed, as, for example, when Budé is appointed secretary to the King of France, and the fact is duly noted in the address. The correspondence with Budé shows that it is possible to carry on a quarrel within the salutations. When his relations with Erasmus reached a low point, Budé varied the traditional formula and wrote Gulielmus Budaeus, hactenus Erasmi amicus, ultimam salutem dicit Erasmo / 'From Guillaume Budé, his erstwhile friend, to Erasmus with best wishes, and never again' (Ep 896); and Erasmus replied: Erasmus Roterodamus $G$. Budaei perpetuus velit nolit amicus, non ultimam sed iugem ac perennem illi dicit salutem / 'Erasmus of Rotterdam, perpetual friend of Guillaume Budé whether he will or no, wisheth him all prosperity, not for the last time, and may it last for ever and ever' (Ep 906)!

What Erasmus objected to most of all was the monstrous flatteries which some writers attached to the salutations of their letters and which (apparently) some dignitaries expected. He makes fun of such appellations as 'treasure-house of learning, 'ever-shining lantern of religion,' 'hammer of heresiarchs,' and 'golden candlestick of the seven liberal arts.' The translator has his own reasons for objecting to these phrases, for, when they occur in the middle of an otherwise sensible letter, there is nothing he can do to soften or excuse their intrinsic silliness. Erasmus is prepared to go a certain distance with the fashion, and in the De conscribendis epistolis he gives a long list of suitable epithets and titles, most of which could be paralleled from contemporary manuals. I shall comment briefly on a few of the points which he raises.

First, Erasmus makes a distinction between what one can say in the salutation and what is appropriate in the body of the letter. Apparently it was much more offensive to use flattering terms in the heading than in the letter itself. This conforms to the practice of Erasmus himself, who is generally fairly reserved about the salutation, but is quite prepared to pour on the flattery in the text if the occasion demands it.

Secondly, Erasmus dismisses with ridicule the practice of changing the order of the salutation to put the name of a person of superior rank first. He describes this as 'childish,' but in fact in many of his own letters this is precisely what he does. In writing to popes and emperors and kings he 
generally (though not always) puts the name of the recipient ahead of his own. I think we should be sensitive to this and preserve the order in translation. Whether the modern reader will appreciate Erasmus' delicacy is another matter!

Thirdly, in the De conscribendis epistolis Erasmus manages to avoid to some extent the appalling class consciousness which characterizes the letter manuals. In the earliest of all the manuals which have come down to us, written in the fourth century by the rhetorician Julius Victor, we already have the doctrine that the style of a letter must vary accordingly as it is addressed to a superior, an equal, or an inferior. This doctrine affected not just the style of the letter, but the style of address, and an elaborate etiquette was developed which young students were expected to learn. ${ }^{6}$ The distinctions could be complex. Peter of Blois divided mankind into five classes, each to be addressed in its own proper style. In the late twelfth century Master William established no less than eighteen different divisions, nine for the clergy and nine for the secular orders. Erasmus had little patience with such theorizing. He attacks what he calls the 'superstition of epithets,' by which he means a slavish adherence to set formulae. He thought it preferable to vary the style of address to suit the particular circumstances or the particular characteristics of his correspondent. The complimentary terms which he approves are traditional enough: the pope is 'most blessed' (beatissime papa), other bishops are amplissimi, kings are invicti, dukes are illustres, and so on. We are warned against confusing the categories: we must avoid calling a girl 'venerable' or an old man 'charming' or a married woman 'unconquerable'! An incompetent theologian should not be called 'erudite'; it would be better, Erasmus suggests, to address him as 'most impressive.' So much for theory; in practice Erasmus reveals himself as much more traditional, especially when he is addressing someone of importance or someone on whose favour he is dependent.

And now to the problems of translation. Clearly it is not possible to reproduce all of the variations which sixteenth-century practice allowed and some expressions simply resist being turned into English. But in vicw of the importance which Erasmus and his contemporaries attached to these matters, we should try to be as consistent as we can and to keep as closely to the Latin as English usage will allow. In a brief article it is not possible to deal with all of the issues, but I conclude with a short selection of representative problems which call for comment.

First let us look at the word reverendus and its superlative reverendissimus and the abstract form tua reverentia. In the early centuries of the church 
this latter term was used for all ranks of clergy and even for laymen and women. But the notion of reverentia was eventually narrowed in its application and tended to be reserved for the higher clergy. The superlative reverendissimus is almost always used in the letters for cardinals, bishops, and abbots, as, for example, in Ep 961: Reverendissimo Domino D. Laurentio Campegio Cardinali Erasmus Roterodamus S.D.

There are three letters in the third volume of Allen (Epp 671, 672, and 720) which have no addressee, but Allen and Peter Bietenholz believe they were written to Wm. Bollart, who was Abbot of Saint-Amond. The recipient is addressed in one of these letters as reverendissime pater and in another as ornatissme pater. Clearly he must have had the status of at least an abbot. The address helps to narrow down the possibilities.

The language in which one can address a pope is naturally somewhat limited. Erasmus seems to prefer beatissime rather than sanctissime, and this was the preferred word in the early history of the church. Should we translate the heading to Ep 335 literally 'To the most blessed father Leo the Tenth'? Our edition has 'To the most holy father, Leo the Tenth' and that will appear more natural to English readers, but it obscures a distinction which exists in the Latin.

Now to one of the commonest words in the language, but one which creates serious problems for the translator. From classical times the word dominus had been used as a term of respect. Seneca tells us that, if we have forgotten someone's name, we can always address him as dominus. ${ }^{7}$ So it must have been roughly equivalent to 'Sir.' But the word never quite lost its sense of dominance or ownership. Erasmus says it should not be used as an honorific title since it implies tyranny. But the word occurs frequently in the letters and it seems to be used freely in many situations and for many classes of people. In our edition it is sometimes omitted and sometimes translated as 'Master' or 'Doctor.' There is a further problem with this word for the translator of Erasmus. In salutations it is generally abbreviated to a single initial. But this can create ambiguities. Does ' $D$ ' stand for dominus or Desiderius? It is unlikely that Erasmus would have referred to himself as dominus; so where we find D. Erasmus Roterodamus in the nominative, we should translate 'Desiderius Erasmus of Rotterdam.' In the letters from the Deventer book Erasmus is often referred to in the salutations as dominus. This occurs so frequently that one suspects editorial tampering. It secms likely that when the letters were collected for publication, some attempt was made at conformity of address, though in fact consistency was not achieved throughout the book. Elsewhere in the correspondence, where the initial is used alone, ambiguity remains. 
There is a peculiar use of this word which calls for comment. It was common practice in salutations to honour the higher clergy by doubling the word dominus. Erasmus attacked the practice, but we find it in his letters not infrequently. For example, Johannes Thurzo, the bishop of Wroclaw, is addressed as follows: Reverendo in Christo patri ac domino, domino Ioanni Turzoni...(Ep 943). The construction of this phrase is not clear. Presumably the first domino is parallel with patri and the second is to be taken with the proper name. But there are other instances where there is nothing which corresponds to patri in this example and the double domino produces a more awkward effect. Clearly we are dealing with a conventional compliment which defies literal translation. All the translator can do is to find some appropriate honorific, which will have to vary with the context. This usage seems to be reserved in Erasmus for the higher clergy. But there is an interesting exception in two letters sent from the patronizing and insufferable Noël Béda, where Erasmus himself is addressed with the double domino (Epp 1605 and 1685): Such an address to one who was neither a bishop nor an abbot is striking, as no doubt it was intended to be. Clearly Béda was flattering Erasmus. But the flattery did nothing to mollify Erasmus' antagonism; for he pointed out that, while Béda called him 'priest' and 'friend,' he never called him 'theologian.' The story shows how sensitive people were to the niceties of titles.

In the De conscribendis epistolis Erasmus says that, if someone calls you magister noster, you should laugh in his face. But that seems to be what he calls Béda in Ep 1679: Ornatissimo magistro nostro Natali Bedae S.P. Given the relations between the two men, one is tempted to interpret this as a deliberate sneer. The same expression is used again in addressing another of Erasmus' correspondents with whom relations were strained, Jan Briart (Ep 670). Magister by itself is not uncommon as a general term of address, particularly in writing to theologians, and it is an entirely complimentary term. But the addition of noster in the two examples cited may possibly add a touch of irony.

In conclusion I should like to make a few remarks about secular titles, which present some complex and interesting problems. Here it is much more difficult to find suitable modern parallels. For one thing, modern titles for high political office vary from country to country and it is not clear what model one should follow. The problem, however, does not lie with specific titles. Expressions like 'the most Christian king of France' are readily accepted in English. It is when we encounter the flattering adjectives which are joined to names and titles that real difficulties arise. We have already seen the class consciousness which is exhibited in 
Francesco Negro's brief treatise on letter-writing. He gives eighteen rules for the salutations, with a list of suitable epithets for each of the orders both spiritual and secular, beginning with the pope and descending gradually to professors and women. The pope, he tells us, may be addressed as 'most pious shepherd of the Lord's flock' and 'the supreme pontiff of the Roman church'; cardinals and other bishops are addressed as amplissimi or venerandissimi or observandissimi; the higher ranks of the laity are praised for their sapientia, spectabilitas and integritas; the middle ranks must be content with prudentia, humanitas, benignitas. Lawyers can be complimented for their probitas, musicians and poets for suavitas, mathematicians for subtilitas and women for pudicitia. Although Negro's treatise was published in Venice in 1488, a mere decade before Erasmus produced the earliest versions of his own De conscribendis epistolis, Erasmus thought it outdated and pedantic (Ep 117). He rejects such 'superstitious' devotion to antiquated rules. Nevertheless it is possible to see some relationship between Negro's rules and Erasmus' practice in his more formal letters. The tradition had not been totally abandoned. In that tradition phrases which look innocent enough sometimes carry a hidden message. There is, for example, a hierarchy of adjectives. Illustris is more complimentary than clarus. A king or a duke may be addressed as a vir illustris. The phrase does not sound particularly grand, but it was one of the titles of the Carolingian kings, and still carried some weight. The adjective amplissimus, which was originally used to mark secular distinction, became the mot juste for bishops and more especially for cardinals. Adjectives like ornatissimus and spectabilis had less of the purple about them and could be used for scholars and theologians, for whom the more grandiloquent titles were thought to be inappropriate.

Not only do many of these honorific titles sound strained in English but it is easy for the translator to convey the wrong impression. Take as an example the phrase tua celsitudo, literally 'your highness.' In modern English this is a title for princes of the royal blood. But it has a much wider reference in the correspondence, where it is used of bishops and archbishops, cardinals, princes, councillors, Henry VIII and Erasmus himself. Clearly 'your Highness' would be an absurd translation in most of these cases. All the translator can do is to employ a suitable title in each place ('your eminence,' 'your lordship,' 'your worship,' etc). The art of translation is the art of compromise.

It will now be clear that it is not possible to develop a grammar for the salutations in Erasmus. The practice which we observe in the correspondence is too varied and individual. Erasmus was, as often, swimming 
between two currents. On the one hand he was impatient with protocol and eager to emulate the simplicity of the ancients. On the other he could not entirely escape convention and many of his more formal letters call to mind the old rules. The tone of a letter may be set in the opening address. The translator should be aware of what the conventions mean.

\section{University of Toronto}

\section{Notes}

1 Francesco Negro Opusculum scribendi epistolas (Venice 1488)

2 The best account of the origin and structure of the salutations is to be found in C.D. Lanham Salutatio: Formulas in Latin Letters to 1200 (Munich 1975).

3 Transmundus in his Ars dictaminis (unpublished) suggests that in writing to a Jew, instead of salutem, one should say fidei claritate totius infidelitatis tenebras propulsare.

4 For vester referring to a single person, see C.J. Fordyce Catullus: A commentary (Oxford 1961), note on 39.20; cf A.E. Housman in Classical Quarterly 3 (1908) $244 f f$.

5 Pliny Epistulae 10.3a.1

6 See Giles Constable 'The structure of Medieval society according to the Dictatores of the twelfth century' in Law, church and society edd K. Pennington and R. Somerville (Philadelphia 1977) 253 - 68.

7 Epistulae ad Lucilium 3.1 